\title{
Iklim Komunikasi Berbasis Kearifan Lokal \\ Studi Kasus Di Pusat Pelatihan Dan Pengembangan Dan Pemetaan Kompetensi Aparatur Sipil Negara LAN-RI Jatinangor
}

\author{
${ }^{1}$ Restie Almha, ${ }^{2}$ Wawan Setiawan Abdillah, ${ }^{3}$ Khaerul Umam \\ ${ }^{1}$ UIN Sunan Gunung Djati Bandung, Indoensia; almaharestie@gmail.com \\ ${ }^{2}$ UIN Sunan Gunung Djati Bandung, Indonesia; wansabdillah.80@uinsgd.ac.id \\ ${ }^{3}$ UIN Sunan Gunung Djati Bandung, Indonesia; umam@uinsgd.ac.id
}

\begin{abstract}
This journal discusses the climate of communication of local wisdom-based organizations in Puslatbang PKASN LAN-RI Jatinangor. Especially the application of the value of local wisdom in the organizational communication climate at the PKATN LAN-RI Jatinangor Puslatbang. The purpose of this research is to find out how Climate Communication of Local Wisdom-based Organizations in PKlatN LAN-RI Jatinangor, to find out the barriers that occur in the climate of communication of local wisdom-based organizations in PKlatN LAN-RI Jatinangor, and find out the efforts made to overcome obstacles in climate communication of local wisdom-based organizations at the PKATN LAN-RI Jatinangor Puslatbang. The study was conducted using the case study method with a qualitative approach. Data collection techniques using interview techniques and study documentation. The results of this study are that the climate of organizational communication based on local wisdom is not yet optimal in terms of the delivery of written information that is difficult for members to understand. And the lack of attention to ethics and values that apply, especially in the achievement of ideas, ideas or information.
\end{abstract}

Keywords: Local Government, Civil Servant, Organizational Communication, Local Wisdom

\section{Pendahuluan}

Menurut Peraturan Presiden RI No. 79 tahun 2018 tentang Lembaga Administrasi Negara (LAN) bahwasannya tiap pemimpin unit organisasi harus mengimplementasikan sistem pengendalian internal pemerintah di lingkungannya masing-masing sebagai perwujudan terlaksananya mekanisme akuntabilitas publik dan pimpinan unit organisasi bertanggung jawab memimpin dan mengkoordinasikan bawahan, memberikan pengarahan, dan petunjuk bagi pelaksanaan tugas bawahan. Setiap lembaga organisasi selalu ingin mempertahankan dan mengembangkan organisasinya. Dalam mengembangkan organisasi salah satunya dengan meningkatan komunikasi organisasi. Komunikasi merupakan aktivitas dasar manusia untuk menyampaikan ide atau pesan. Dengan komunikasi manusia dapat berhubungan satu sama lain, baik dalam kehidupan sehari-hari maupun dalam sebuah organisasi.

Komunikasi yang terjadi didalam suatu organisasi disebut dengan komunikasi organisasi. Komunikasi merupakan elemen penting yang mendasari interaksi antar manusia didalam organisasi. Organisasi bukan hanya sebuah struktur yang baku yang terbentuk dari kumpulan jabatan dan peran saja, melainkan melalui aktivitas komunikasi organisasi itu sendiri. Sesuai dengan Peraturan LAN RI No. 26 Tahun 2017 mengenai Katalog Kompetensi Dan Standar Kompetensi Jabatan Di Lingkungan Lembaga Administrasi Negara Pasal 4 yang berisi jenis kompetensi yang dimuat dalam Katalog Kompetensi dan Standar Kompetensi Jabatan yaitu salah satunya Kompetensi Manajerial yang didalamnya terdapat kompetensi Komunikasi Organisasi. Dalam peraturan tersebut menyebutkan bahwa komunikasi organisasi dapat memberi serta menerima informasi, gagasan, pendapat, atau pesan, baik secara lisan 
maupun tulisan dengan jelas, seperti misal membuat laporan tertulis dengan melakukan presentasi yang komunikatif kepada pihak - pihak yang lain. Selain itu, mampu menjalin komunikasi interpersonal dalam rangka menyelesaikan suatu tugas. Jadi dalam sebuah organisasi atau lembaga komunikasi memiliki peran yang sangat penting, karena komunikasi menjadi dasar interaksi antara bawahan dan atasan dan antar anggota yang satu dengan anggota lainnya.

Komunikasi yang terjadi didalam suatu organisasi tergantung pada iklim komunikasi. Dengan alasan, karena iklim merupakan fungsi bagaimana kepuasan anggota terhadap komunikasi dalam organisasi (Pritchard, 1973). Redding (Pace, 2018), bahkan menyatakan bahwa keterampilan ataupun teknik-teknik komunikasi tidak dapat mewujudkan sebuah organisasi dengan efektif, karena menurutnya iklim komunikasi organisasi lah lebih penting daripada yang harus ada dalam organisasi. Jadi, iklim komunikasi organisasi jauh lebih penting dari pada komunikasi itu sendiri karena teknik dan keterampilan komunikasi tidak menjamin organisasi itu akan berjalan secara efektif. Iklim komunikasi merupakan keadaan karakteristik yang terjadi di lingkungan kerja yang dianggap dapat mempengaruhi perilaku anggota organisasi.

Dengan harapan organisasi berjalan secara efektif, Pusat Pelatihan Dan Pengembangan Dan Pemetaan Kompetensi Aparatur Sipil Negara (Puslatbang PKASN) LAN-RI Jatinangor juga membangun iklim komunikasi organisasi dengan menerapkan nilai-nilai yang berlaku salah satunya nilai yang bersumber dari nilai kearifan lokal. Lembaga tersebut merupakan lembaga yang melaksanakan pengkajian dan inovasi pengembangan instrument di bidang Pemetaan Kompetensi Aparatur Sipil Negara.

Sesuai dengan Peraturan Kepala Pusat Pelatihan Dan Pengembangan Dan Pemetaan Kompetensi Aparatur Sipil Negar Lembaga Administrasi Negara Nomor: 109/PKA.1.1/HKM.02.1 Tentang Kode Etik Aparatur Sipil Negara Di Lingkungan Pusat Pelatihan Dan Pengembangan Dan Pemetaan Kompetensi Aparatur Sipil Negar Lembaga Administrasi Negara Pasal 4 yang berisi core values Puslatbang PKASN LAN RI. Pasal tersebut menjelaskan mengenai core values atau nilai-nilai dasar yang terlah disepakati oleh pegawai di lingkungan Puslatbang PKASN LAN-RI yang terdiri atas: Integritas; Profesional; Inovatif; Peduli; SAHATE. Salah satu nilai dasar disana bersumber dari kearifan lokal yaitu nilai SAHATE. Dimana kata tersebut diserap dari bahasa Sunda sesuai dengan lokasi keberadaan Puslatbang PKASN LAN-RI itu berada yakni di daerah Jawa Barat tepatnya di Jatinagor. Kata 'Sahate' berasal dari bahasa sunda yang berarti sehati atau satu hati. Kata SAHATE yang digunakan oleh Puslatbang PKASN LAN-RI Jatiangor sebagai nilai budaya organisasinya merupakan singkatan dari SAntun, HArmonis, TEgas. Nilai SAHATE sebagai upaya perwujudan satu tujuan dalam rangka membangun Puslatbang PKASN LAN-RI, sesuai dengan Pasal 9, yang berisi Penjabaran nilai SAHATE yang dimaksud dalam pasal 4 huruf e adalah sebagai berikut:

a. Memahami dan menghormati keragaman dari masing pribadi/ kelompok;

b. seluruh kegiatan dilakukan dari hati, berdasarkan kecintaan dan pengabdian pada lembaga;

c. Berupaya untuk mewujudkan satu tujuan demi membangun Puslatbang PKASN;

d. Bersikap santun dalam berinteraksi dengan orang lain;

e. Menjaga keharmonisan dalam lingkungan kerja;

f. Tegas dalam menegakkan aturan. 
Nilai SAHATE ini diaplikasikan atau diterapkan dalam segala aspek, termasuk dalam perilaku komunikasi organisasi dengan tujuan untuk menjaga keharmonisan dalam lingkungan kerja. Hal ini sesuai dengan hasil wawancara yang peneliti lakukan pada 20/10/2019 dengan Bapak Octa Rian selaku Staff Analis Kepegawaian mengatakan bahwa :

"Memang betul nilai SAHATE ini nilai kearifan lokal di organisasi ini dan tidak terdapat di organisasi manapun ya, dan ini menjadi nilai dasar yang disepakati oleh seluruh pegawai, ya tentunya nilai ini harus kami terapkan dalam segala hal, tidak terkecuali dalam iklim komunikasi juga kami terapkan."

Berdasarkan hasil wawancara diatas, menunjukan bahwa nilai SAHATE ini diterapkan dalam iklim komunikasi organisasi di Puslatbang PKASN LAN-RI Jatinangor. Adapun hasil pengamatan atau observasi partisipan, ialah suatu wujud observasi khusus dimana peneliti tak hanya menjadi pengamat yang pasif, melainkan juga sebagai pengambil beberapa peran didalam situasi tertentu yang dapat berpartisipasi dalam peristiwa-peristiwa yang hendak diteliti (Yin, 2009). Hasil dari pengamatan partisipan dilembaga tersebut, yaitu komunikasi serta hubungan yang terjalin antara atasan dan bawahan terjalin cukup baik, ditunjukan dengan komuninakasi interpersonal yang dirasakan oleh peneliti selama berpartisipasi disana.

Adapun dalam penerapannya, pegawai belum optimal dalam menerapkan nilai SAHATE kedalam iklim komunikasi. Pegawai di Puslatbang PKASN LAN-RI Jatinangor masih belum memahami penjabaran yang terkandung dari nilai SAHATE. Sebagaimana yang telah disampaikan oleh Ibu Eius selaku Kepala Bagian Administrasi saat dilakukan wawancara menyatakan bahwa masih banyak pegawai yang menyampaikan pesan atau informasi dengan tidak memperhatikan etika dan nilai-nilai yang berlaku.

Permasalahan yang ada di Puslatbang PKASN LAN-RI diindikasi karena:

a. Adanya sifat ego sektoral yang cukup tinggi dalam masing-masing unit di Puslatbang PKASN LAN-RI Jatinangor. Hal ini di buktikan dari hasil wawancara.

b. Minimnya perhatian pada etika serta nilai-nilai yang berlaku. Hal ini di buktikan dari hasil wawancara.

c. Penyampaian informasi atau mengkomunikasikan informasi tertulis atau tidak tertulis yang terkadang sulit dipahamai oleh pegawai. Hal ini dibuktikan dari hasil wawancara.

d. Perbedaan persepsi dan penggunaan bahasa atau nada bicara yang berbeda. Hal ini di buktikan dari hasil wawancara.

Adapun permasalahan yang ditemukan oleh peneliti pada objek penelitian dapat diselesasikan dengan teori iklim komunikasi organisasi yang dikemukakan oleh Pace dan faules (Pace, 2018), yaitu :

a. Kepercayaan

b. Pembuatan keputusan bersama

c. Kejujuran

d. Keterbukaan terhadap komunikasi hingga bawah

e. Mendengarkan komunikasi keatas

f. Perhatiaan pada tujuan-tujuan yang berkinerja tinggi 
Sebagaimana yang diungkapkan Dwight Waldo (Pasolong, 2017), administrasi publik adalah mengelola dan mengorganisasikan anggota dan peralatannya untuk mencapai tujuan pemerintah. Selanjutnya Nicholas Henry (Pasolong, 2017), administrasi publik ialah suatu paduan antara teori dengan praktik yang bertujuan mempromoasi pemahaman terhadap pemerintah yang berhubungan dengan rakyat, juga mendorong kebijakan publik agar lebih responsif terhadap kebutuhan sosial. Sedangkan David H. Rosenbloom (Pasolong, 2017), menunjukan pemanfaatan teori dan proses manajemen, politik dan hukum untuk memenuhi kebutuhan pemerintah di bidang legislative, eksekutive, dalam rangka memberikan pelayanan terhadap masyarakat secara keseluruhan merupakan administrasi publik.

Dari beberapa definisi yang dipaparkan diatas, penulis dapat menarik kesimpulan bahwa yang dimaksud dengan administrasi publik adalah serangkaian kegiatan kerjasama yang dilakukan oleh sekelompok orang atau oleh sebuah lembaga dalam melaksanakan tugas pemerintahan untuk memenuhi kebutuhan publik. Tujuan administrasi publik disini yaitu untuk memenuhi kebutuhan publik.

Salah satu kajian Administrasi Publik yaitu Perilaku Organisasi. Nicholas Henry (Pasolong, 2017), memberikan rujukan tentang ruang lingkup administrasi publik yakni: Organisasi publik, yang pada prinsipnya berkaitan dengan model organisasi dan juga perilaku organisasi; Manajemen publik, ialah berkaitan dengan sistem juga ilmu manajemen, evaluasi program dan produktivitas, anggaran publik dan manajemen sumber daya menusia; Implementasi yaitu menyangkut pendekatan terhadap kebijakan publik dan implementasinya, privatisasi, administrasi antar instansi dan etika birokrasi. Berdasarkan ruang lingkup administrasi tersebut yang sesuai dengan penelitian ini yakni iklim komunikasi berbasis kerarifan lokal termasuk ke dalam ruang lingkup organisasi publik yang berkenaan dengan perilaku organisasi

Tujuan dari penelitian ini yaitu mengetahui Iklim Komunikasi Organisasi berbasis Kearifan Lokal di Puslatbang PKASN LAN-RI Jatinangor; hambatan didalam Iklim Komunikasi Organisasi berbasis Kearifan Lokal di Puslatbang PKASN LAN-RI; serta Upaya untuk mengatasi hambatan yang terjadi pada Iklim Komunikasi Organisasi berbasis Kearifan Lokal di Puslatbang PKASN LAN-RI Jatinangor.

\section{Metode Penelitian}

Penelitian ini dilakukan dengan menggunakan metode studi kasus, pendekatan penelitian kualitatif. Metode penelitian menggunakan metode studi kasus yang bertujuan menjelaskan dan memahami obyek yang ditelitinya secara khusus sebagai suatu kasus. Penelitian ini menggunakan pendekatan kualitatif, dimana dalam penelitian kualitatif ini mengahasilkan dan mengolah data yang sifatnya deskriptif. Menurut Moleong, penelitian kualitatif yaitu penelitian untuk memahami fenomena tentang apa yang dialami oleh subjek penelitian. seperti perilaku, persepsi, motivasi, tindakan dll., secara holistik dengan cara deskripsi dalam bentuk kata-kata dan bahasa, pada suatu konteks khusus yang alamiah dan dengan memanfaatkan berbagai metode alamiah (Moleong, 2011).

Penelitian dilakukan di Puslatbang PKASN LAN-RI Jatinangor. Penelitian dilakukan pada April hingga Juli tahun 2020 dengan menggunakan pedoman wawancara sebagai instrument penelitian. Adapun objek penelitian ini adalah pada iklim komunikasi organisasi berbasis kearifan lokal.

Teknik pengumpulan data dilakukan menggunakan wawancara dan studi dokumentasi. Adapun untuk informan wawancara dilakukan dengan empat orang dengan rincian sebagai berikut: (1) Kepala Bagian Administrasi Puslatbang PKASN LAN-RI, (2) Staff Analis 
Kepegawaian Puslatbang PKASN LAN-RI, (3) Staff Pelatihan dan Pengembangan Puslatbang PKASN LAN-RI, (4) Koordinator Barang dan Jasa Puslatbang PKASN LAN-RI. Adapun untuk studi dokumentasi yang digunakan dalam penelitian ini yaitu menggunakan dokumen buku kode etik Puslatbang PKASN LAN-RI.

Adapun untuk teknik analisis data menggunakan teori model Miles and Huberman dalam (Silalahi, 2010) yaitu analisis data kualitatif dilakukan dengan cara interaktif dan berlangsung secara terus-menerus hingga tuntas, sampai data sudah terpenuhi. Terdapat tiga proses yang dapat dipakai untuk menganalisis data kualitatif, yaitu: mereduksi data, menyajikan data, dan menarik kesimpulan.

\section{Hasil Dan Pembahasan}

Dari hasil penelitian tentang Iklim Komunikasi Organisasi Berbasis Kearifan lokal di Puslatbang PKASN LAN-RI Jatinangor yang dilakukan oleh peneliti menggunakan Teori Iklim Komunikasi Organisasi Pace dan Faules, maka peneliti akan memberikan pembahasan sebagai berikut.

Dilihat dari sisi Kepercayaan anggota terhadap lembaga, tingkat kepecayaan anggota sangat tinggi terhadap lembaga. Hal ini dibuktikan dengan adanya keyakinan untuk memberikan loyalitas yang tinggi dan kredibilitas berupa kinerja yang tinggi. Untuk mengetahui loyalitas dan kredibilitas yang diberikan oleh anggota dengan diadakannya evaluasi setiap bulan. Untuk meningkatkan kepercayaan anggota terhadap lembaga yaitu dengan selalu terbuka atau transparan mengenai iformasi-informasi yang berkaitan dengan lembaga. Terbuka dalam arti tidak ada informasi yang tambahkan atau dikurangi dengan kata lain informasi yang utuh. Dengan demikian anggota akan merasa percaya atas semua informasi yang disampaikan. Selain itu, nilai SAHATE juga di terapkan dalam meningkatkan kepercayaan anggota terhadap lembaga, salah satunya nilai Tegas. Dimana nilai tegas ini menjadi suatu pedoman dalam keberanian untuk menyampaikan informasi secara terbuka dan utuh.

Pembuatan keputusan di Puslatbang PKASN LAN-RI Jatinangor biasanya melibatkan anggota dalam prosesnya. Anggota selalu diberi kesempatan untuk berkomunikasi dan berkonsultasi dalam menyelesaikan suatu masalah. Informasi dan laporan-laporan atau gagasan dan ide dari anngota menjadi salah satu inspirasi dalam pembuatan keputusan dan kebijakan. Dan pimpinan atau manajmen selalu mengikutsertakan anggota bertujuan agar terciptanya keselarasan antara kebijakan, pimpinan dan anggota. Dengan demikian sasaran dari kebijakan pun akan tercapai sesuai dengan kehendak pimpinan dan anggota. Dalam pengambilan keputusan bersama ini, nilai-nilai organisasi selalu menjadi pedoman. Salah satunya nilai SAHATE. Dalam hal ini salah satu nilai SAHATE yaitu nilai Tegas menjadi satu pedoman atau nilai yang diterapkan. Alasanya karena nilai tegas ini sangat diperlukan dalam pengambilan keputusan bersama agar ada pertanggung jawaban dari suatu keputusan.

Dilihat dari sisi kejujuran, maksud kejujuran disini adah keterbukaan informasi. Di Puslatbang PKASN LAN-RI Jatinangor ini terbagi menjadi beberapa unit atau bagian. Maka dari itu kejujuran atau keterbukaan informasi sangat diperlukan. Alasannya, karena di organisasi ini proses kerjanya saling keterkaitan dan tidak bisa berdiri atau berjalan sendiri. Jadi anggota dituntut untuk selalu terbuka atas segala hal yang ada dipikiran mereka yang tentunya terkait dengan organisasi. Hal ini dilakukan demi tercapainya tujuan-tujuan organisasi. Kejujuran atau keterbukaan informasi ini sangat penting selain demi pencapaian tujuan, yaitu demi keharmonisan suasana kerja. Mengingat nilai-nilai yang berlaku salah 
satunya nilai SAHATE yaitu nilai Harmonis. Dengan adanya kejujuran dan keterbukaan informasi ini diharapkan adanya hubungan kerja yang harmonis dan sinergis.

Keterbukaan informasi dari atas kebawah di Puslatbang PKASN LAN-RI Jatinangor sangat sederhana dan mudah untuk diperoleh. Pihak manajmen selalu memberikan informasi secara terbuka dan kemudahan untuk pegawai dalam memperoleh informasinya. Pemberian informasi secara terbuka melalui rapat, diskusi, meet up Senin pagi, dan WhatsApp Group. Namun dalam informasi yang diberikan secara tertulis sering didapati kesulitan pegawai untuk memahami isi dari informasinya dikarenakan penggunakan kata-kata yang baku sehingga sulit dicerna.

Pihak manajmen atau atasan selalu mendengarkan informasi dan laporan-laporan atau ide, gagasan, masukan dari anggotanya. Dari hasil wawancara menunjukan bahwa pimpinan selalu dengan bijaksana dan fast response dalam menanggapi informasi, laporan, ide, gagasan dan masukan dari anggota.. Bagaimanapun isi dan penyampaian informasi dari bawahan, pimpinan berusaha untuk tetap bijaksana dan tegas dalam menganggapinya. Dan penyampaian informasi yang dilakukan oleh sluruh anggota pun tetap berdasarkan pada nilai SAHATE yaitu nilai santun, dengan tujuan agar suasana kerja yang harmonis tetap terjaga. Dalam hal ini inilai SAHATE sangat berperan, baik itu dari nilai Tegas yang diberikan oleh pimpinan, nilai santun yang diberikan oleh pegawai dan keharmonisan yang selalu mereka jaga.

Perhatian yang ditujukan pada tujuan organisasi di Puslatbang PKASN LAN-RI Jatinangor ini dapat dilihat dari adanynya komitmen anggota dalam mencapai sasaran. Hal ini ditandai dengan selalu diadakannya evaluasi untuk menilai kinerja pegawai dan pemberian reward. Hal ini tentunya membuat anggota bersemangat dan berlomba-lomba dalam meningkatkan produktivitas dan kualitas kerjanya. Dalam membangun komitmen ini, nilai SAHATE juga diterapkan didalamnya. Salah satunya terlihat dari ketegasan pihak manajmen dalam pemberian nilai kinerja dengan adanya reward dan punishment.

Dalam iklim komunikasi berbasis kearifan lokal di Puslatbang PKASN LAN-RI Jatinangor terdapat beberapa hambatan beserta upaya yang dilakukan untuk mengatasi hambatan tersebut, yaitu:

Pertama, adanya sifat ego sektoral dari masing-masing unit. Masing-masing unit terlalu menonjolkan kepentingan unitnya sendiri tanpa memperhatikan unit-unit lain. Ego sektoral in tentunya menjadi hambatan dalam proses komunikasi yang berdampak pada keharmonisan suasana kerja dan pencapaian tujuan. Hal ini dikarenakan di Puslatbang PKASN LAN-RI Jatinangor ini terdiri dari beberapa unit yang saling berkaitan satu sama lain. Apabila terjadi perpecahan antara unit satu dengan yang lain akibat sifat ego sektoral ini, maka tujuan organisasipun tidak akan tercapai sesuai sasaran. Selain itu, akibat dari sifat ego sektoral ini akan merusak keharmonisan suasana kerja dilingkungan organisasi. Hal ini dapat diatasi dengan selalu mengingatkan nilai-nilai SAHATE terutama nilai Harmonis. Dengan harapan setiap kegiatan yang dilakukan di organisasi itu berjalan harmonis dan sinergis. Upaya yang dilakukan untuk Mengingatkan nilai SAHATE itu sendiri yaitu dengan selalu menyisipkan nilai-nilai SAHATE didalam segala hal dan kesempatan. Secara visual selalu menghadirkan logo, simbol, infografis yang mengingatkan pada nilai-nilai SAHATE. Selain itu, melalui media komunikasi WhatsApp Group yang diberi nama SAHATE.

Kedua, kurangnya perhatian pada etika dan nilai-nilai yang berlaku. Hal ini ditunjukan dengan seringkali mendapati penyemapaian informasi atau pendapat pegawai yang tidak sesuai dengan etika dan nilai yang berlaku. Hal ini disebabkan karena setiap orang memiliki persepsi yang berbeda dan emosional yang berbeda pula yang tidak dibekali dengan etika dan nilai organisasi. Di Puslatbang PKASN LAN-RI Jatinangor ini sendiri memberikan kebebasan 
dalam menyampaikan informasi dan pendapat namun harus sesuai etika dan nilai yang berlaku. Untuk mengatasi hal ini, pihak manajmen berupaya untuk selalu saling mengingatkan akan nilai dan etika yang berlaku, yaitu nilai SAHATE. Dimana nilai santun harus diperhatikan dan diterapkan dengan cara mengajak anggota untuk bersama-sama menyuarakan pendapatnya dengan nilai santun. Selain itu, pihak manajmen juga selalu berusaha untuk tidak tersulut emosi yang sama dan meberikan pengarahan kearah yang lebih baik.

Ketiga, adanya kesulitan dalam memahami informasi yang disampaikan secara tertulis. Informasi tertulis yang disampaikan dapat melalui media WhatsApp atau surat edaran. Informasi tertulis ini dapat menyebabkan kesalahpahaman persepsi. Dalam nyatanya, tidak semua pegawai atau anggota dapat memahami isi yang terkandung dari informasi tertulis tersebut. Hal ini tentunya menjadi hambatan dalam proses komunikasi yang dapat berdampak pada kinerja pegawai. Upaya yang dilakukan untuk mengatasi hambatan ini yaitu dengan menyampaikan ulang informasi oleh pimpinan masing-masing unit. Hal ini disebutkan dapat lebih efektif karena tim pelaksana dapat berhadapan langsung dengan pimpinan unitnya dan tidak sungkan untuk menanyakan hal-hal yang tidak dipahami dalam informasi tersebut.

Keempat, kesalahpahaman akibat perbedaan persepsi dan penggunaan bahasa dan nada bicara yang berbeda. Perbedaan persepsi ini selalu menyelimuti proses komunikasi di Puslatbang PKASN LAN-RI Jatinangor, karena terdiri dari beberapa unit. Persepsi-persepsi yang muncul itu berbeda tergantung dengan kepentingan masing-masing unit. Penggunaan bahasa dan nada bicara yang berbeda pula menjadi salah satu hambatan. Alasanya, karena anggota organisasi tidak semuanya berasal dari daerah yang sama. Jadi perbedaan bahasa dan penekanan bicara yang muncul itu biasanya menyembabkan kesalahpahaman antara pemberi informasi dan penerima informasi. Upaya yang dilakukan dalam mengatasi hambatan ini yaitu dengan diadakannya komunikasi lebih lanjut. Komunikasi lebih lanjut itu dengan diadakannya diskusi, rapat, evaluasi. Dalam pengguanaan bahasa dan nada bicara yang berbeda-beda sesuai dengan daerah masing-masing, upaya yang dilakukan yaitu dengan menerapkan nilai SAHATE terutama nilai santun. Diusahakan menggunakan bahasa dan nada bicara yang sopan dan santun yang sesuai dengan bahasa nasional atau bahasa Indonesia.

\section{Simpulan}

Iklim komunikasi organisasi berbasis kearifan lokal yaitu dengan nilai SAHATE di Puslatbang PKASN LAN-RI Jatinangor belum maksimal.. Pertama, dilihat dari dimensi Kepercayaan sudah baik, Pihak manajmen selalu berusaha meningkatkan kepercayaan anggota terhadap organisasi. Kedua, dilihat dari dimensi Pengambilan Keputusan Bersama sudah baik, anggota atau pegawai selalu diberi kesempatan untuk berkonsultasi dan berkomunikasi mengenai masalah terkait dengan organisasi.Sumber daya belum optimal, hal ini dikarenakan belum adanya sosialisasi maupun peningkatan kompetensi pemustaka dalam rangka pencegahan pelanggaran hak cipta. Ketiga, dilihat dari dimensi Kejujuran atau penyampaian pendapat secara terbuka belum optimal, karena dalam penyampaiannya sering didapati pegawai yang tidak memperhatikan etika dan nilai-nilai yang berlaku. Keempat, dilihat dimensi Keterbukaan Komunikasi Kebawah belum optimal, yaitu informasi yang disampaikan secara tertulis kepada seluruh pegawai seringkali sulit dipahami dan dicerna oleh pegawai atau anggota. Kelima, dilihat dari dimensi Mendengarkan Komunikasi Keatas sudah baik, dimana atasan selalu mendengarkan dan menanggapi dengan bijaksana laporan, informasi, dan pendapat dari anggota. Keenam, dilihat dari dimensi Perhatian Pada Tujuan-tujuan Berkinerja Tinggi sudah baik, pegawai memiliki komitmen yang tinggi terhadap organisasi. 


\section{Referensi}

Moleong, L. J. (2011). Metodologi Penelitian Kualitatif edisi Revisi. Bandung: PT. Remaja Rosdakarya.

Pace, R. W. \& D. F. F. (2018). Komunikasi organisasi: Strategi meningkatkan kinerja perusahaan Ed. Deddy Mulyana (D. Mulyana, ed.). Bandung: PT. Remaja Rosda Karya.

Pasolong, H. (2017). Teori Administrasi Publik. Bandung: Alfabeta.

Peraturan Presiden RI No. 79 tahun 2018 Tentang Lembaga Administrasi Negara (LAN)

Peraturan Lembaga Administrasi Negara Republik Indonesia No. 26 Tahun 2017 Tentang Katalog Kompetensi Dan Standar Kompetensi Jabatan Di Lingkungan Lembaga Administrasi

Peraturan Kepala Pusat Pelatihan Dan Pengembangan Dan Pemetaan Kompetensi Aparatur Sipil Negar Lembaga Administrasi Negara Nomor: 109/PKA.1.1/HKM.02.1 Tentang Kode Etik Aparatur Sipil Negara Di Lingkungan Pusat Pelatihan Dan Pengembangan Dan Pemetaan Kompetensi Aparatur Sipil Negar Lembaga Administrasi Negara

Pritchard, R. D. \& K. B. W. (1973). The Effects Of Organizational Climate On Manajerial Job Performance and Job Satisfaction. Organizational Behavior and Human Performance, 9.

Silalahi, U. (2010). Metode Penelitian Sosial (A. Gunarsa, ed.). Bandung: PT Refika Aditama. 